\title{
Turkish adaptation, validity, and reliability of the Peer Aggression Coping Self-Efficacy Scale (PA-CSES)
}

\author{
Orkide Bakalım ${ }^{1}$ \\ Fatma Selda Öz $z^{2}$
}

\begin{abstract}
The present study aimed to adapt Peer Aggression Coping Self-Efficacy Scale to Turkish version. Data were gathered from 639 students in grades 6, 7, 8 and 9. As a result of explanatory analysis carried out to test the construct validity of PA-CSES, a four factor construct was also confirmed by the Turkish students. Apart from this, as a result of analysis, girls level of self-efficacy for avoiding aggressive behavior, self efficacy for proactive behavior and self-efficacy for avoiding selfblame were much higher than those of boys. In addition, the students' in grade 6 , level of selfefficacy for avoiding aggressive behavior, self efficacy for proactive behavior, self-efficacy for victim- role disengagements were also much higher than those of the students in grade 9. The findings were discussed in terms of literature and some suggestions were proposed for further studies.
\end{abstract}

Keywords: Peer; aggression; coping self-efficacy; scale adaptation.

\section{Introduction}

Peer aggression is defined as a series of aggressive behaviours which children and teenagers use against each other (Calaguas, 2011). These series of aggressive behaviours consist of insulting, hurting physically and social violence (Singh\&Bussey, 2009; Calaguas, 2011). In literature, it is striking that the concept of peer aggression and peer bullying is interchangeable. In some sources, the definitions of these two concepts are given differently (Gökler, 2009). According to Olweus (1997), bullying actions comprise aggression. But the concept of bullying means a relationship of inequal power between the sides. Besides, that permanent relationship and deliberation in aggressive behaviors are the characteristics of peer bullying (Olweus, 1997; Pişkin, 2005; Gökler, 2009). On the contrary to this, inequality of powers or infrequent aggressive behaviour does not

1 Assist. Prof. Dr., Uşak University, Faculty of Educational Sciences, Guidance and Counseling Program, orkide1605@gmail.com

2 Lecturer, Dokuz Eylül University, Faculty of Educational Sciences, Guidance and Counseling Program, seldaoz.oz@gmail.com 
Bakalım, O., \& Öz, F. S. (2014). Turkish adaptation, validity, and reliability of the Peer Aggression Coping Self-Efficacy Scale (PA-CSES). International Journal of Human Sciences, 11(2), 827-841. doi: 10.14687/ijhs.v11i2.2921

always happen (Pişkin, 2002; Totan \& Yöndem, 2007; Gökler, 2009; Hunter, Boyle \& Warden, 2004). For instance, although that two people having approximately the same physical and mental powers argue or fight with each other has the quality of aggression, the action is not regarded as bulling. Similarly that a student attacks another student met for the first time physically and verbally for various reasons cannot be called bullying, because of infrequency of the behaviour (Totan \&Yöndem, 2007). In the context of this study, the term peer aggression is going to be used as infrequent aggressive behaviours existing in the similar age groups are to be handled .

Peer aggression is a problem which is common among children and teenagers at schools and has been very common all over the world recently (Pişkin, 2002; Graham, Belmore\&Mize, 2006; Karataş, 2009; Totan, 2008; Singh\&Bussey, 2009; Uzbaş, 2009; Singh\&Bussey, 2010; Calaguas, 2011; Uz Baş, Öz \&Kabasakal, 2012). In the last three decades, this problem has been increased extensively and observed commonly among the teenagers aged 11-16 (Gallup, Obrain \&Wilson, 2010). Hoover,Oliver \& Hazler (1992) concluded that \% 77 of secondary school students were victims of peer aggresssion. In the study put down that the cases of peer aggression and bullying reported by different countries were between \%4 and \% 50 (Pişkin, 2002; Gökler, 2009). White, Gallup \& Gallup (2010) conducted a research on healthy behaviours of the school age children in 25 countries and concluded that between $\% 9$ and $\% 54$ of the school age children were victims of aggression or they themselves attacked their friends or both of the situations were experienced. In the close examination related to some research on the extension of peer aggression all over the world the ratios of the students, victims of peer aggression were summarized as follows; $\% 30-50$ in Australia, \%28-40 in Italy,\%4-36 in England, \% 15-30 in Greece, \% 20-22 in Portuguese, \% 21 in Canada, \% 10 in the USA ,\% 10 in Norway. In Turkey, it has been known that peer aggression is a common problem at schools and there has been an increase in the cases of aggression and bullying (Ministry of National Education, 2006; Genç, 2007; Şahan, 2007; Totan \&Yöndem, 2007; Karataş, 2009; Öz, Kırımoğlu \& Temiz, 2011). According to a report by the research committee in the Turkish Grand National Assembly, in Turkey, in 2006-2007 Academic Year, when it was examined the situation of the high school students encountering peer aggression, it was found out that $\% 22$ of them were subjected to physical attack, $\% 53$ of them were victims of verbal aggression, $\% 26,3$ of them were victims of emotional aggression in the last three months.

Some descriptive researches have been conducted in Turkey and generally focused on the extention, reasons, relationship between variables of peer aggression (Şahan, 2007; Totan \&Yöndem, 2007; Totan, 2008; Özdinçer, 2008; Tipırdamaz, 2008; 
Bakalım, O., \& Öz, F. S. (2014). Turkish adaptation, validity, and reliability of the Peer Aggression Coping Self-Efficacy Scale (PA-CSES). International Journal of Human Sciences, 11(2), 827-841. doi: 10.14687/ijhs.v11i2.2921

Yaban, 2010; Öz, Kırımoğlu \&Temiz, 2011). In addition to some descriptive research, there have been some experimental studies aimed at decreasing aggression (Akdeniz, 2007; Karataş, 2009; Yavuzer \& Üre, 2010; Uz Baş, 2010).

Along with the extension of peer aggression, the number of research focused on negative psychological symptoms which might occur among the children and teenagers victims of peer aggression by desk mates has increased day by day(Graham,Bellmore\&Mize,2006). Some of the research proved that high level of depression, anxiety, anger, feelings of hopelessness, worthlessness, unhappiness, disliking the school, low self-esteem and thoughts about death among the children and teenagers who were victims of peer aggression were observed much more than ones among those who weren't subjected to peer-aggression (Hawker \& Boulton, 2000; Hanish \& Guerra, 2002; Genç, 2007; Şahan, 2007; Totan \& Yöndem, 2007; Gökler, 2009; Karataş, 2009; White, Gallup \& Gallup, 2010). Moreover, it has been explained that a tendency to show agressive behaviours by the teenagers suffering from aggression is also higher (Graham, Bellmore \& Mize,2006; Şahan, 2007). On the other hand, among some of the teenagers who are victims of peer-aggression, these kinds of negative results were not observed (Singh \& Bussey, 2009). This situation showed that not only peer-aggression caused negative psychological results, but also there were some variables that contribute to these results. It has been explained that these variables might occur as a result of interactions between certain situations about the case of aggression (repetition of the action and its duration) and their individual inner (cognitive and emotional) and behavioural factors (Singh\&Bussey,2009).It is also stated that one of the individual factors might affect the psychological reactions given by the children and teenagers in case of negative experience like peer aggression is to coping self-efficacy (Singh \& Bussey, 2009; Singh \& Bussey, 2010).

Coping self-efficacy is to be defined as self-belief about which a person can react efficiently against threatening situations or environment (Özer \& Bandura,1990; Bandura,1993; Bandura, 1997; Benight \& Harper, 2002; Johnson \& Benight, 2003; Benight, Harding-Taylor, Midboe\& Durham, 2004; Benight \& Bandura, 2004; Hulberti \& Morrison, 2006; Chesney,Neilands, Chambers, Taylor \& Folkman, 2006). if a person believes in himself that he can react appropriately against the traumatic or challenging situation, he might be less stressful and tensed. But, if the level of coping self-efficacy is low, it is expected that the level of stress is also high (Bandura, 1993; Bandura,1997; Johnson \& Benight, 2003). 

Scale (PA-CSES). International Journal of Human Sciences, 11(2), 827-841. doi: 10.14687/ijhs.v11i2.2921

It is striking that most of the samples on coping self-efficacy were taken from adult population. The limited research about coping self-efficacy in adolescence is an important gap (Singh \& Bussey, 2009). With regard to this, it has been known that being a victim of peer-aggression is a traumatic experience for children and teenagers. Coping self-efficacy is an important individual reference to cope with this traumatic experience (Singh \& Bussey, 2009; Singh \& Bussey, 2010).

\section{Purpose}

It has been considered that a measurement device which assesses coping self-efficacy with peer aggression has our country supplied could be pioneer research of descriptive and experimental research about coping self-efficacy with peer aggression. Moreover, this study will enable interventions aimed at developing methods of coping with peer aggression efficiently. Therefore, this study aimed that Peer Aggression Coping Self-Efficacy Scale (Singh \& Bussey,2009) is to be adapted to Turkish and that the Turkish language and its literature will have been supplied after its validity and reliability have been worked on.

\section{Method and material}

\subsection{Sample}

Data were collected from 639 students in grades 6, 7, 8 and 9 in Mavişehir Primary School, Ankara Primary School, Ilkkurşun Primary School, Mehmet Ali Lahur Trade High School, Suzan Divrik Girls High School and Illkkurşun High School in 2011-2012 Academic Year, in the province of Izmir. 158 students (78 girls, 80 boys) were in grade 6, 162 students ( 86 girls,76 boys) in grade 7 , 154 students ( 76 girls, 78 boys) in grade 8,165 students ( 82 girls, 83 boys) in grade 9 .

\subsection{Data collection}

\subsubsection{Data collection method}

At first, it was taken permission from the school administrations in which the study was going to be applied to work validity and reliability of the scale. The students were given information about the purpose of the study. All of the students accepted to participate in the study. Scales were given to the students in the classroom. PA-CSES-T and GSES were applied at the same time. It took about 45 minutes. The data were picked up by the researchers.

\subsubsection{Data collection tools}

Peer Aggression Coping Self Efficacy Scale (The PA-CSES) The PA-CSES has been developed by Singh and Bussey to determine the adolescents, victims of peer aggression, level of 
coping self efficacy with peer aggression, the scale consists of four domains. These domains were obtained as a result of explanatory factor analyses. They are 1.Self-efficacy for proactive behaviour, 2. Self-efficacy for avoiding aggressive behaviour, 3. Self-efficacy for avoiding self-blame, 4. Selfefficacy for victim role disengagement.

The validity of PA-CSES was examined by self-consistency. As a result of the calculations, it was found out that Cronbach Alpha correlation for the domain of self-efficacy for pro-active behaviour was 0.87, Cronbach Alpha correlation for the domain of self-efficacy for avoiding aggressive behaviour was 0.90 , Cronbach Alpha corelation for the domain of self-efficacy for avoiding selfblame was 0.90, and Cronbach Alpha correlation for the domain of self-efficacy for victim-role disengagement was 0.90 .

For this study, PA-CSES was first translated into Turkish by some researchers and an English interpreter. A teaching assistant retranslated the items from Turkish into English. Later these translations were restudied on by a counselor having good command of The English language and three teaching assistants having doctor's degree. The items got their final formation in parallel with teaching assistants feedbacks. On the other hand, since it was hard to find students from grades 6,7,8 and 9 who mastered both Turkish and English in the province of Izmir and apply them on students, that the translations were checked by three specialist was accepted for the validity of language and Turkish version of Peer Aggression Coping Self Efficacy Scale (PA-CSE-T) was completed.

General Self-Efficacy Scale (The GSES) The scale was first developed by Shwarser \& Jerusalem in Germany. In 1993 the English version of the scale was developed by the same researchers, later by various researchers it was translated into 26 languages and adapted. The scale aimed at making an overall evaluation about self-efficacy consists of 10 items. After conducting the research in 23 countries, it was observed that the values for the Cronbach Alpha coefficient of internal consistency ran between .76 and .90.The Cronbach Alpha coefficient for internal consistency was .79 for the sample group consisting of 639 people.

\subsection{Evaluation of data}

The criterion validity and the confirmatory factor analysis (CFA) was used to test if the PA-CSES fits with the Turkish data. For the criterion validity analysis GSES and PA-CSES-T were applied to the same group and the correlation between scale scores were calculated with Pearson Product 
Bakalım, O., \& Öz, F. S. (2014). Turkish adaptation, validity, and reliability of the Peer Aggression Coping Self-Efficacy Scale (PA-CSES). International Journal of Human Sciences, 11(2), 827-841. doi: 10.14687/ijhs.v11i2.2921

Moment Correlation Coefficients. Lisrel 8.7 was used to run CFA. CFA results were evaluated by using these indices:Chi-Square Goodness of Fit $\left(\chi^{2}\right)$, Root Mean Square Error of Approximation (RMSEA) ,Goodness of Fit Index (GFI), Adjusted Goodness of Fit Index (AGFI), Root Mean Square Residuals (RMR), Standardized Root Mean Square Residuals (SRMR), Normed Fit Index (NFI) and Comparative Fit Index (CFI). Modification indices were examined to improve the model structure for two times.

Two methods were used to determine the reliability of the scale. First, the scale was applied to 52 people twice within one month intervals to be able to use the method of participants determination of test retest reliability. The Cronbach Alpha Correlation Co-efficient was calculated as the second method to measure the internal consistency of the items consisting of the scale.

On the other hand in order to determine whether peer aggression differ according to gender and grade level the t-test and ANOVA were used respectively.

\section{Results}

\subsection{Results of criterion validity analysis}

Pearson Product Moment Correlation Coefficients between two scales were found as 0.75 . This result shows that the relationship between total points for the scales was considerably high.

\subsection{Results of confirmatory factor analysis}

The results of the confirmatory factor analysis indicated that a four factor model of the scale, based on the study of the Singh \& Bussey (2009), was confirmed. When the confirmatory factor analysis and sample data fit are examined, fit and error statistics like chi-square $\left(\chi^{2}\right), \chi^{2} / \mathrm{sd}, \operatorname{RMSEA}, \mathrm{RMR}$, GFI, AGFI, CFI are used. That calculated statistics values for $\chi^{2} / \mathrm{sd}<5$, GFI and AGFI $>0,9$, RMR and RMSEA $<0.05$ prove that model data fit is perfect. (Jöreskog ve Sörbom 1993; Marsh ve Hocevar 1988). In addition to this, the values of $\mathrm{GFI}<0,85$, AGFI $<0,80$, RMR and RMSEA $<0.10$ are the acceptable lower bound for model data fit (Anderson \& Gerbing1984; Marsh, Balla \& McDonald, 1988). The statistics about fit of the results of the confirmatory factor analysis are given in table 1.

Table 1. Values of Goodness of Fit tests for PA-CSES.

\begin{tabular}{lllllllllll}
\hline $\begin{array}{l}\text { Chi- } \\
\text { Square }\end{array}$ & Df & CFI & NFI & GFI & AGFI & IFI & SRMR & RMSEA & $\begin{array}{l}\% 90 \\
\text { RMSEA }\end{array}$ & C.I. \\
\hline 3048,03 & 894 & 0,95 & 0,92 & 0,97 & 0,96 & 0,95 & 0,055 & 0,061 & 0,059 & 0,064 \\
\hline
\end{tabular}



Scale (PA-CSES). International Journal of Human Sciences, 11(2), 827-841. doi: 10.14687/ijhs.v11i2.2921

When Table 1 is studied on chi square value divided by degrees of freedom was found as 3,4._This value is a sign of fit of the model and the data. At the same time, values for CFI, NFI, GFI, AGFI are IFI are over 0,90 .This situation shows that there is a highly good fit between the model and the data. When error indices are examined, that the value for SRMR showing the model fit about its standardized errors is $<0,8$ is the sign of fit of the model and the data. It is seen that the value for RMSEA covers the value of 0,06 with $\% 90$ probability. This situation proves that the fit of the data and the model is high (Hu \& Bentler, 1999). When all of the values about the data and model fit about the scale are looked into, it can be said that the constructed model is highly consistent with the data and for this reason the scale has the construct validity. It can be accepted that the items forming the scale constructed a latent variable of PA-CSES-T. The path diagram that contains the standart values of the confirmatory factor analysis is shown in figure 1. 


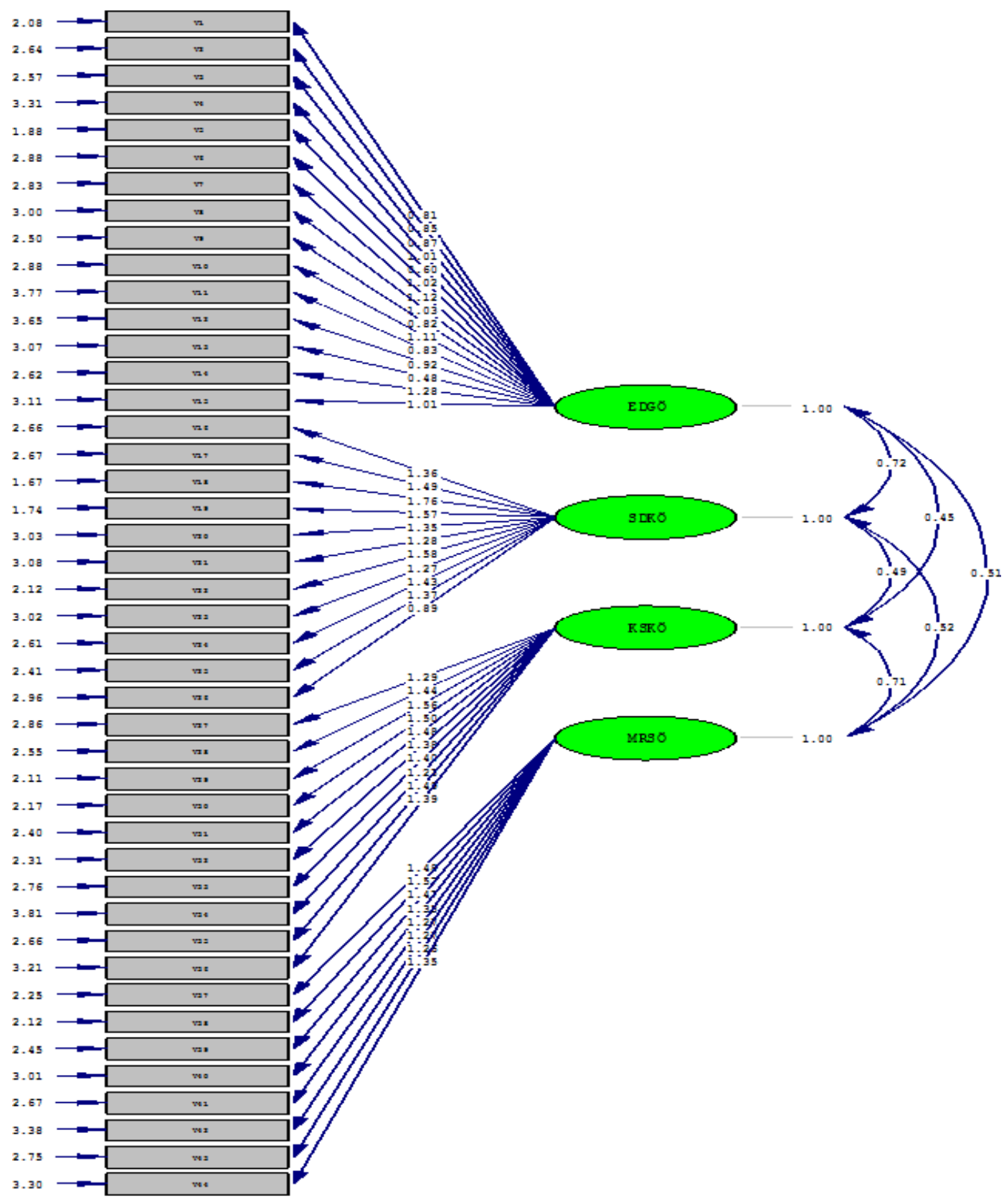

Figure 1. Diagram of the Confirmatory Factor Analysis applied on the items of Peer Aggression Coping Self-Efficacy Scale (PA-CSES-T)

\subsection{Results of reliability analysis}

It was concluded that the correlation coefficient between two points got by the students from the scale was 0.891 . This calculated value was the proof that the scale evaluated the participants consistently at different times. 
Bakalım, O., \& Öz, F. S. (2014). Turkish adaptation, validity, and reliability of the Peer Aggression Coping Self-Efficacy Scale (PA-CSES). International Journal of Human Sciences, 11(2), 827-841. doi: 10.14687/ijhs.v11i2.2921

The Cronbach Alpha Correlation Co-efficient was calculated to measure the internal consistency of the items consisting of the scale. The result was 0.934 . The co-efficients of the reliability for the domains of the scale were worked out separately and the results were as follows: 0.82 for selfefficacy for proactive behaviours, 0.89 for self-efficacy for avoiding aggressive behaviour, 0.86 for self-efficacy for avoiding self-blame, 0.85 for self-efficacy for victim-role disengagement. It was accepted that PA-CSES-T was reliable enough because the co-efficient of test-retest and internal consistency was high.

\subsection{Study of PA-CSES-T by gender and grade level}

Irrelevant samples and retest were used to examine whether domains of PA-CSES Scores differed by gender and grade levels. In this way, it was found out whether there was a meaningful difference between girls and boys average scores in their total scores of domains.

Table 2. Results of self-efficacy for pro-active behaviour scores by gender

\begin{tabular}{lllllll}
\hline Gender & $\mathrm{n}$ & $\bar{X}$ & $\mathrm{~S}$ & $\mathrm{sd}$ & $\mathrm{t}$ & $\mathrm{P}$ \\
\hline Female & 322 & 75.43 & 14.081 & 637 & 4.519 & .000 \\
Male & 317 & 69.98 & 16.310 & & & \\
\hline
\end{tabular}

Table 2 illustrates that Self-Efficacy for Pro-Active Behaviour scores are different and statistically and significant in favor of females. $(\mathrm{t}=4.519, \mathrm{p}<0.05)$

Table 3 . Results of self-efficacy for avoiding aggressive behaviour scores by gender

\begin{tabular}{lllllll}
\hline Gender & $\mathrm{n}$ & $\bar{X}$ & $\mathrm{~S}$ & $\mathrm{sd}$ & $\mathrm{t}$ & $\mathrm{P}$ \\
\hline Female & 322 & 49.75 & 16.284 & 637 & 3.826 & .000 \\
Male & 317 & 44.86 & 16.000 & & & \\
\hline
\end{tabular}

Table 3 illustrates that Self-Efficacy for Avoiding Aggressive Behaviour scores are different and statistically significant in favour of girls. $(\mathrm{t}=3.826, \mathrm{p}<0.05)$

Table 4.Results of self-efficacy for avoiding self-Blame scores by gender

\begin{tabular}{lllllll}
\hline Gender & $\mathrm{n}$ & $\bar{X}$ & $\mathrm{~S}$ & $\mathrm{sd}$ & $\mathrm{t}$ & $\mathrm{P}$ \\
\hline Female & 322 & 50.54 & 15.356 & 637 & 3.497 & .001 \\
Male & 317 & 46.29 & 15.322 & & & \\
\hline
\end{tabular}

Table 4 shows that Self-Efficacy For Avoiding Self-Blame Scores are different and statistically significant on behalf of girls. $(\mathrm{t}=3497, \mathrm{p}<0,05)$.

Table 5. Results of self-efficacy for victim-role disengagement scores by gender

\begin{tabular}{lllllll}
\hline Gender & $\mathrm{n}$ & $\bar{X}$ & $\mathrm{~S}$ & $\mathrm{sd}$ & $\mathrm{t}$ & $\mathrm{P}$ \\
\hline Female & 322 & 36.70 & 12.426 & 637 & 1.181 & .238 \\
Male & 317 & 35.57 & 11.692 & & & \\
\hline
\end{tabular}


Bakalım, O., \& Öz, F. S. (2014). Turkish adaptation, validity, and reliability of the Peer Aggression Coping Self-Efficacy Scale (PA-CSES). International Journal of Human Sciences, 11(2), 827-841. doi: 10.14687/ijhs.v11i2.2921

When table 5 is scanned, it is realized that Self-Efficacy for Avoiding Self-Blame scores are not statistically different by gender.

Whether the domains of PA-CSES-T were different among grade levels was examined with variance analysis. Descriptive statistics for Self-Efficacy for Pro-Active Behaviour scores were shown in Table 6.

Table 6 .Descriptive statistics for self-efficacy for pro-active behaviour scores by grade level.

\begin{tabular}{|c|c|c|c|}
\hline Grade & $\mathrm{n}$ & $\overline{\bar{X}}$ & SS \\
\hline 6 & 158 & 74.90 & 15.788 \\
\hline 7 & 162 & 75.52 & 13.641 \\
\hline 8 & 154 & 71.29 & 15.146 \\
\hline 9 & 165 & 69.24 & 16.363 \\
\hline
\end{tabular}

Table 7. ANOV A results for self-efficacy for pro-active behaviour by grade levels.

\begin{tabular}{lllllll}
\hline & $\begin{array}{l}\text { Total } \\
\text { Squares }\end{array}$ & df & $\begin{array}{l}\text { Average } \\
\text { Squares }\end{array}$ & F & Sig. & $\begin{array}{l}\text { Meaningful } \\
\text { Difference }\end{array}$ \\
\hline Intergroups & 4333.685 & 3 & 1444.562 & 6.194 & .000 & $6-9.7-9$ \\
In Groups & 148104.935 & 635 & 233.236 & & & \\
Total & 152438.620 & 638 & & & & \\
\hline
\end{tabular}

As it is seen in Table 7, the results of the analysis signify that students' level for Self-Efficacy for Pro-Active Behaviour differ meaningfully by grade levels $\mathrm{F}(3.635)=6.194, \mathrm{p}>.01$. As a result of Sheffe Test, the students', in grade 6 (74.90) and in grade 7 (75.52), levels for Peer Aggression Coping Self-Efficacy were higher than those of students in grade 9.

Table 8. Descriptive statistics for self-efficacy for avoiding aggressive behaviour scores by grade levels.

\begin{tabular}{|c|c|c|c|}
\hline Grade & $\mathrm{n}$ & $\bar{X}$ & ss \\
\hline 6 & 158 & 51.58 & 16.561 \\
\hline 7 & 162 & 49.28 & 15.264 \\
\hline 8 & 154 & 44.80 & 15.451 \\
\hline 9 & 165 & 43.70 & 16.767 \\
\hline
\end{tabular}

Table.9. ANOV A Results for self-efficacy for avoiding aggressive behaviour scores by grade levels

\begin{tabular}{lllllll}
\hline & $\begin{array}{l}\text { Total } \\
\text { Squares }\end{array}$ & df & $\begin{array}{l}\text { Avarage } \\
\text { Squares }\end{array}$ & F & Sig. & $\begin{array}{l}\text { Meaningful } \\
\text { Difference }\end{array}$ \\
\hline Intergroups & 6636.103 & 3 & 2212.034 & 8.607 & .000 & 6-9.7-8. 7-9 \\
In groups & 163200.539 & 635 & 257.009 & & & \\
Total & 169836.642 & 638 & & & & \\
\hline
\end{tabular}


Bakalım, O., \& Öz, F. S. (2014). Turkish adaptation, validity, and reliability of the Peer Aggression Coping Self-Efficacy Scale (PA-CSES). International Journal of Human Sciences, 11(2), 827-841. doi: 10.14687/ijhs.v11i2.2921

As Table 9 represents the results of the analysis that students' level of Self-Efficacy for Avoiding Aggressive Behaviour differentiate meaningfully by grade level $\mathrm{F}(3.635)=8.607 . \mathrm{p}>.01$. According to Sheffe Test Results students' in grade 6 (51.58) and grade 7 (49.28) level was found much higher than that of students in grade 9 (43.70). Besides, students' level of Self-Efficacy Coping with Peer Aggression in grade 7 (49.28) was found much higher than that of the students in grade 8 (44.80).

Table 10. Descriptive statistics for self-efficacy for avoiding self-blame scores by grade level

\begin{tabular}{|c|c|c|c|}
\hline Grade & $\mathrm{n}$ & $\bar{X}$ & ss \\
\hline 6 & 158 & 49.35 & 15.614 \\
\hline 7 & 162 & 48.46 & 14.844 \\
\hline 8 & 154 & 49.52 & 14.174 \\
\hline 9 & 165 & 46.52 & 16.990 \\
\hline
\end{tabular}

Table 11. ANOV A results for self-efficacy for avoiding self-blame scores by grade level.

\begin{tabular}{lllllll}
\hline & $\begin{array}{c}\text { Total } \\
\text { Squares }\end{array}$ & df & $\begin{array}{c}\text { Avarage } \\
\text { Squares }\end{array}$ & F & Sig. & $\begin{array}{c}\text { Meaningful } \\
\text { Difference }\end{array}$ \\
\hline Intergroups & 921.083 & 3 & 307.028 & 1.284 & .279 & \\
In Groups & 151829.706 & 635 & 239.102 & & & \\
Total & 152750.789 & 638 & & & & \\
\hline
\end{tabular}

As it is seen in Table 11, variance analysis showed that there are not statistically significant differences among Self-Efficacy for Avoiding Self-Blame Scores by grade level.

Table 12. Descriptive statistics for self-efficacy for victim-role disengagement scores by grade level.

\begin{tabular}{|c|c|c|c|}
\hline Grade & $\mathrm{n}$ & $\overline{\bar{X}}$ & SS \\
\hline 6 & 158 & 39.04 & 11.762 \\
\hline 7 & 162 & 36.67 & 11.883 \\
\hline 8 & 154 & 35.07 & 12.235 \\
\hline 9 & 165 & 3385 & 11.889 \\
\hline
\end{tabular}

Table 13. ANOV A results for self-efficacy for victim-role disengagement scores by grade level.

\begin{tabular}{lllllll}
\hline & $\begin{array}{l}\text { Total } \\
\text { Squares }\end{array}$ & df & $\begin{array}{l}\text { Avarage } \\
\text { Squares }\end{array}$ & F & Sig. & $\begin{array}{l}\text { Meaningful } \\
\text { Difference }\end{array}$ \\
\hline Intergroups & 2419.924 & 3 & 806.641 & 5.657 & .001 & 6-8. 6-9 \\
In Groups & 90542.116 & 635 & 142.586 & & & \\
Total & 92962.041 & 638 & & & & \\
\hline
\end{tabular}


Bakalım, O., \& Öz, F. S. (2014). Turkish adaptation, validity, and reliability of the Peer Aggression Coping Self-Efficacy Scale (PA-CSES). International Journal of Human Sciences, 11(2), 827-841. doi: 10.14687/ijhs.v11i2.2921

As it is seen in Table 13, the results of analysis show that students level for Self-Efficacy for Victim-Role Disengagement has a meaningful difference by grade level $\mathrm{F}(3.635)=5.657 \mathrm{p}>.01$. According to Sheffe Test Results, students' level in grade 6 (39.04) for Self-Efficacy for VictimRole Disengagement was higher than that of students in grade 9 (33.85).

\section{Discussion}

The main purpose of this study is to adapt PA-CSES developed by Singh and Bussey to Turkish. The confirmatory factor analysis (CFA) was used to get proof for the validity of PA-CSES-T like in the original scale. As a result of the analysis, high scores for goodness of fit were reached. Moreover high results of criterion analysis seems to support the validity of the scale. In addition, it was accepted that PA-CSES-T was reliable enough because the co-efficient of test-retest and internal consistency was also high.

The other results of the study proved that girls levels for self-efficacy for pro-active behaviour, selfefficacy for avoiding aggressive behaviour, self-efficacy for avoiding self-blame were higher than those of boys'. In their study Singh and Bussey (2009), girls' levels for self-efficacy for pro-active behaviour and self-efficacy for avoiding aggressive behaviour were also found higher. According to Singh and Bussey, this result revealed that boys are socialized more individually than girls, whereas girls have a tendency to look for social support. However, it has been stated that aggression is more acceptable among boys and they are encouraged about it by their parents and their tendency for aggressive reaction to aggressive attack is also higher (Singh \& Bussey, 2009).

Besides this study, students in grade 6 their level for self-efficacy for pro-active behaviour, selfefficacy for avoiding aggressive behaviour and self-efficacy for victim-role disengagement was found higher than students in grade 9. This result is parallel to the study by Singh \&Bussey (2009). In this study Singh \& Bussey (2009) associated the result with the features of ages. In the period which adolescents older than 14, there are a lot of social and psychological factors which might affect their self-efficacy and emotional lives. Furthermore, in this period, adolescents' self-criticism might make their belief in self-efficacy differ (Singh\&Bussey.2009).

\section{Conclusions and recommendations}

In this study PA-CSES-T was examined psychometrically and findings proved that the instrument could be useful. Individuals in the sample include students attending the schools in İzmir. In the further studies, preference of samples from different schools and cities will enable to get more 
Bakalım, O., \& Öz, F. S. (2014). Turkish adaptation, validity, and reliability of the Peer Aggression Coping Self-Efficacy Scale (PA-CSES). International Journal of Human Sciences, 11(2), 827-841. doi: 10.14687/ijhs.v11i2.2921

information on PA-CSES-T. For further research coping self-efficacy for peer aggression can be examined with various variances.

Additionally, the scale might be used in elementary, secondary and high schools by Psychological Counseling and Guidance Service. Thus, psychological counselors at schools can help the students, who are victims of peer aggression to cope with the aggression efficiently. And also findings reached at the end of the study might be a guide in formation of counseling programs.

\section{References}

Akdeniz. M. (2007). Öfke kontrolü eğitiminin lise ögrencilerinde öfke kontrolü becerilerine etkisi. (The effect of anger control skills on high school students' anger control training). Unpublished master thesis. Çukurova Üniversitesi Sosyal Bilimler Enstitüsü. Adana.

Anderson. J. C. \& Gerbing. D. W. (1984). The effect of sampling error on convergence. imperoper solutions and googness-fit indicesfor maximum likelihood confirmatory factor analysis. Psycometrica. 49. 155-173

Arslan. S. (2008). Lise ögrencilerinde özkavram ve aile iliskisinin akran zorbalğgna etkisi. (The effect of family and self concept relation on peer bullying in high school students.) Unpublished doctoral thesis . İstanbul Üniversitesi Sağllk Bilimleri Enstitüsü: İstanbul.

Bandura. A. (1993). Perceived self-efficacy in cognitive development and functioning. Educational Psychologist. 28. 117-148.

Bandura. A. (1997). Self-efficacy. Harvard Mental Health Letter. 13(9).

Benight. C.C. \& Harper. M.L. (2002). Coping self-efficacy perceptions as a mediator between acute stress response and long-term distress following natural disasters. Journal of Traumatic Stress. 15. 177-186.

Benight. C.C. \& Bandura. A. (2004). Social cognitive theory of posttaumatic recovery: the role perceived self-efficacy. Behaviour Research and Therapy. 42. 1129-1148.

Benight. C.C.. Harding-Taylor. A.S.. Midboe . A.M. ve Durham. R.L. (2004). Development and psychometric validation of a domestic violence coping self-efficacy measure (DV-CSE). Journal of Traumatic Stress. 17. 505-508.

Büyüköztürk. Ş. (2012). Sosyal Bilimler için Veri Analizi El Kitabı İstatistik. Araștırma Deseni SPSS Uygulamalar ve Yorum (16. Bask1). Ankara: PEGEM

Calaguas. G. (2011). The incidence of peer aggression and peer victimization between the sexes. International Journal of Human Sciences. 8. 151.

Chesney. M.A.. Neilands. T.B.. Chambers. D.B.. Taylor. J.M. \& Folkman. S. (2006). A validity and reliability study of the coping self efficacy scale. British Journal of Health Psychology. 11. 421437.

Gallup. A.C.. O'Brien. D.T. \& Wilson. D.S. (2010). The relationship between adolescent peer aggression and responses to a sequental prisoner's dilemma game during college: an explorative study. Journal of Social. Evolutionary and Cultural Psychology. 4. 277-289.

Genç. G. (2007). Genel liselerde akran zorbah̆ğ ve yönetimi. [Peer bullying and its management in high schools]. Unpublished doctoral thesis. İnönü Üniversitesi Sosyal Bilimler Enstitüsü. Malatya.

Gökler. R. (2009). Okullarda akran zorbalığ1 [Peer bullying in schools]. Uluslararası Insan Bilimleri Dergisi. 6 (2).

Graham. S.. Bellmore. A.D. \& Mize. J. (2006). Peer victimization. aggression and their cooccurence in middle school: Pathways to adjustment problems. Journal of Abnormal Child Psychology. 34. 363-378. 
Bakalım, O., \& Öz, F. S. (2014). Turkish adaptation, validity, and reliability of the Peer Aggression Coping Self-Efficacy Scale (PA-CSES). International Journal of Human Sciences, 11(2), 827-841. doi: 10.14687/ijhs.v11i2.2921

Hanish. L.D.\& Guerra. N.G. (2002). A longitudinal analysis of patterns of adjustment following peer victimization. Develolopment and Psychology. 14. 69-89.

Hawker. D.S.\& Boulton. M.J. (2000). Twenty years research on peer victimization and psychosocial maladjustment : a meta analytic review of cross-sectional studies. Journal of Child Psychology and Psychiatry. 41. 441-455.

Hoover. J.H.. Oliver. R. \& Hazler. R.J. (1992). Bullying: perceptions of adolescent victims in midwestern USA. School Psychology International. 13. 5-16.

Hu. L -T. \& Bentler. P. M. (1999). Cut-off criteria for fit indexes in covariance structure analysis: Conventional criteria versus new alternatives. Structural Equation Modeling. 6.1-55

Hulberti. N.J. ve Morrison. V.L. (2006). A preliminary study into stres in paliative care: optimism. self efficacy and social support. Psychology. Health ve Medicine. 11. 246-255

Hunter. S; Boyle. J. \& Warden. D. (2004). Help seeking among child and adolescent victims of peer aggression and bullying: The influence of school stage. gender. victimisation. appraisal and emotion. British Journal of Educational Psychology. 74. 375-390.

Johnson. L.E. and Benight. C.C. (2003). Effects of trauma-focused research on recent domestic violence survivors. Journal of Traumatic Stress. 16. 567-571.

Jöreskog. K.G. and Sörbom. D. (1993). LISREL 8: Structural Equation Modeling with the SIMPLIS Command Language. New Jersey: Lawrence Erlbaum Associates Puplishers.

Karataş. Z. (2009). Bilişsel-davranışçı teknikler kullanılarak yapılan öfke yönetimi programının ergenlerin saldırganlığını azaltmadaki etkisi. [The Effect of Anger Management Programme through Cognitive Behavioral Techniques on the Decrease of Adolescents Aggression]Pamukkale Üniversitesi Eğitim Fakültesi Dergisi. 26. 12-24.

Marsh. H. W. \& Hocevar. D. (1988). A new more powerful approachto multitrait-multimethod analyses: application of second-order confirmatory factor anaylsis. Journal of Applied Psychology. 73.107-117.

Marsh. H. W.. Balla. J. R..\& McDonald. R. P. (1988). Googness-of-fit indexes in confirmatory factor analysis: The effect of sample size. Psychological Bulletin. 103. 391-410.

Milli Eğitim Bakanlığ1 (2006). Eğitim ortamında siddetin önlenmesi ve azaltılmasi strateji ve eylem plan (20062011). Ankara: Milli Eğitim Bakanlığı Özel Eğitim ve Rehberlik Genel Müdürlüğü.

Olweus. D. (1997). Bully/victim problems in school: facts and intervention. European Journal of Psychology of Education. 12 (4). 495-510).

Öz. A.Ş.. Kırımoğlu. H. \& Temiz. A. (2011). İlköğretim 2. kademe öğrencilerinin spor yapma durumlarına göre zorbalık eğilimleri ve zorbalıkla baş etme tarzlarının spor ve özel eğitim açılarından incelenmesi (From special and physical education point of view: a study on junior high students bullying tendencies and ways to cope with bullying depending on the level of playing sports). Selçuk Üniversitesi Beden Eğitimi ve Spor Bilim Dergisi. 13. 237-245.

Özer. E.M. \& Bandura. A. (1990). Mechanism governing empowerment effects: a self analysis. Journal of Personality and Social Psychology. 3. 472-486.

Pişkin. M. (2002). Okul zorbalığ1: Tanımı. türleri. ilişkili olduğu faktörler ve alınabilecek önlemler. (School Bullying: Definition, types, related factors and strategies to prevent bullying problems). Kuram ve Uygulamada Egitim Bilimleri. 2 (2). 531-562.

Pişkin. M. (2005). Ankara Valiliği İl Milli Eğitim Müdürlüğü. Özel Eğitim Rehberlik ve Psikolojik Danışma Hizmetleri Bölümü “Okullarda Şiddet” Paneli. Ankara: 12 Ocak 2005.

Schwarzer. R. \& Jerusalem. M. (1979). General Self-Efficacy Scale. In R. Schwarzer (Ed.). Self efficacy: Thought control of action (pp. 195-213).

Singh. P \& Bussey. K. (2009). The development of a peer aggression coping self-efficacy scale for adolescents. British Journal of Developmental Psychology. 27. 971-992.

Singh. P \& Bussey. K. (2010). Peer victimization and psychological maladjustment: The mediating role of coping self-efficacy. Journal of Research on Adolescence. 1 -14. 
Bakalım, O., \& Öz, F. S. (2014). Turkish adaptation, validity, and reliability of the Peer Aggression Coping Self-Efficacy Scale (PA-CSES). International Journal of Human Sciences, 11(2), 827-841. doi: 10.14687/ijhs.v11i2.2921

Şahan. M. (2007). Lise ögrencilerinde salderganlŭg yordayan değğşkenlerin incelenmesi. (An examination of some variables which predict high school students aggression). Unpublished master thesis. Gazi Üniversitesi Eğitim Bilimleri Enstitüsü. Ankara.

TBMM Araştırma Komisyonu Raporu (2007). Türkiye Büyük Millet Meclisi çocuklarda ve gençlerde artan siddet eğilimi ile okullarda meydana gelen olaylarn arastirlarak almmasi gereken önlemlerin belirlenmesi amacylla kurulan meclis araștırması komisyon raporu. Ankara: Özel Eğitim ve Rehberlik Danışma Hizmetleri Genel Müdürlüğü.

Tipırdamaz Sipahi. H. (2008). İzmir ili Bornova ilçesinde ilkögretim 6. ve 7.sme ögrencilerinde akeran zorbalğg. etkileyen ve esslik eden faktörler. (Bullying in sixth and seventh grade primary school students in Bornova region of Izmir province and its determinants and associated factors). Unpublished doctoral thesis. Ege Üniversitesi Sağlık Bilimleri Enstitüsü. İzmir.

Totan. T. \& Yöndem. Z.D. (2007). Ergenlerde zorbalı̆̆ın anne. baba ve akran ilişkileri açısından incelenmesi. (The investigation of bullying in adolescence related to parent and peer relations). Ege Eğitim Dergisi. 8. 53-68.

Totan. T. (2008). Ergenlerde zorbahğm anne. baba ve akran ilişkileri açısndan incelenmesi. (The investigation of bullying in adolescence related to parent and peer relations). Unpublished master thesis. Abant Izzet Baysal Üniversitesi Sosyal Bilimler Enstitüsü. Bolu.

Uz Baş. A. (2010). Sınıf temelli bir soysa beceri eğitimi programının ilköğretim dördüncü sınıf öğrencilerinin güvengenlik ve saldırganlık düzeyleri üzerindeki etkisi.( The effects of a classroom based social skills training program on the levels of assertiveness and aggressiveness of fourth grade elementary school students). Uluslararasi Insan Bilimleri Dergisi. 7 (2). 732-747.

Uz Baş. A.. Öz. F.S. \& Kabasakal. Z. (2012). İlköğretim ve ortaöğretim okullarında reaktif ve proaktif saldırganlık: okul psikolojik danışmanlarının görüş ve yaklaşımları. (Reactive and proactive aggression in elementary and high schools:School counselors' views and approaches). Mehmet Akif Ersoy Üniversitesi Eg̈itim Fakültesi Dergisi. 23. 354-370.

White. D.D.. Gallup. A.C. \& Gallup. G.G. (2010). Indirect peer aggression in adolescence and reproductive behavior. Evolutionary Psychology. 49-65.

Yaban. E.H. (2010). Ergenlerin arkadaşhk niteliği. ebeveynden ve okul ortaminda ögretmenden algzlanan destek ile akran zorbaligr/zorbaliğa maruz kalma arasindaki iliskiler.( The relations among adolescents? friendship quality, perceived parental support, teacher support in school climate and peer bullying/victimization ). Unpublished master thesis. Hacettepe Üniversitesi Sosyal Bilimler Enstitüsü. Ankara.

Yavuzer. Y. \& Üre. Ö. (2010). Saldırganlı̆̆ önlemeye yönelik psikoeğitim programının lise öğrencilerindeki saldırganlığ1 azaltmaya etkisi.(The effect of psycho-education program towards preventing aggression on decreasing aggressiveness of high school students) . Selçk Üniversitesi Sosyal Bilimler Enstitüsü Dergisi. 24. 390-405. 